DOI: $10.2478 / \mathrm{v} 10047-011-0033-6$

\title{
SCHEMES FOR COMPENSATION OF CHROMATIC DISPERSION IN COMBINED HDWDM SYSTEMS
}

\author{
V. Bobrovs, A. Udalcovs, S. Spolitis, G. Ivanovs \\ Institute of Telecommunications, Riga Technical University, \\ 12 Azenes Str., Riga, LV-1048, LATVIA
}

\begin{abstract}
The authors seek best ways to realize chromatic dispersion (CD) compensation schemes for differently modulated optical signals in high-speed mixed data rate HDWDM systems. The research is based on OptSim 5.1. simulation software, which numerically solves nonlinear Schrödinger equation using the split-step Fourier method. It is shown that the CD compensation scheme is crucial for the performance evaluation in combined HDWM transmission channels. Therefore, a scheme of the type is proposed that is suited best for a very complicated combined fiber optical transmission system. It is also found that asymmetrical CD compensation schemes in pre- and post-compensation modules are the most efficient, allowing the best BER in a channel to be achieved.

Key words: high density wavelength division multiplexing (HDWDM), chromatic dispersion (CD) compensation methods, differential phase shift keying with non-return-to zero coding (NRZ-DPSK), binary-state polarization shift keying (2POLSK), on-off keying with NRZ coding (NRZ-OOK), fiber Bragg grating (FBG), optical phase conjugator (OPC), dispersion compensating fiber (DCF).
\end{abstract}

\section{INTRODUCTION}

In the last few years dramatic increase in the demand for information transmission capacity has been observed. The existing transmission systems will be unable anymore to secure appropriate quality of service (QoS) if a number of worldwide internet users - on the one hand, and the data volume per user - on the other continue to grow $[1,2]$. This demand is mainly due to the expansion and variety of new information services (including the data, internet, online and broadband services) and their rapid advance. As a result, the internet traffic is continuing its skyrocketing growth, and, even by reasonably conservative estimates, keeps doubling every year. To satisfy the demand for a channel's bit rate and transmission capacity, the bandwidth currently required in optical transmission systems used in the backbone networks has steeply increased and doubles every two years. One of the most cost-effective capacity increments in a fiber optical transmission system (FOTS) could be achieved by increasing the total transmission capacity of the optical fiber used [3].

Currently, one of the most intensively studied solutions for raising the total transmission capacity of a fiber is to increase the number of transmitting channels, and, simultaneously, to do this for the bit rate per channel. In the wavelength division multiplexing (WDM) systems, increase in the number of transmitting channels can be achieved by reducing the channel spacing and using new 
transmission bands, such as S-band (1460-1530 nm) and $L$-band $(1565-1625 \mathrm{~nm})$ in addition to the $C$-band $(1530-1565 \mathrm{~nm})$ [3]. At the same time, a reduction in the channel spacing leads to amplification of transmission impairments. One of the ways to minimize this factor is implementation of advanced modulation formats, e.g. NRZ-DPSK or 2-POLSK, for the channels that are the most affected by such impairments as optical pulse broadening and nonlinear effects in optical fibers. Another task is that of transmitting over a single fiber optical link differently modulated optical signals in the case of different transmission systems' merger or (which may occur in the nearest future) at switching traffic from a variety of WDM systems [2].

In turn, topical is the increase in the bit rate per channel, since the main costformation factor is the use of traditional modulation format: a system's cost is usually doubled at the bit rate increasing from $10 \mathrm{Gbit} / \mathrm{s}$ to $40 \mathrm{Gbit} / \mathrm{s}$ if a NRZOOK modulation format for signal is applied [4]. Here we should take into account that the transmitter and especially the receiver units are more expensive for advanced modulation formats than for the NRZ-OOK one. Increasing the bit rate per channel by a factor of four, we should adhere to the dispersion management strategy $[5,6]$. The maximum affordable accumulated chromatic dispersion (CD) level for a $10 \mathrm{Gbit} / \mathrm{s}$ NRZ-OOK channel is $\sim 1000 \mathrm{ps} / \mathrm{nm}$, while for the same modulation format in the case of $40 \mathrm{Gbit} / \mathrm{s}$ bit rate it is only $60 \mathrm{ps} / \mathrm{nm}-$ i.e. the error-free transmission for a standard single mode fiber (SSMF) is possible over $60 \mathrm{~km}$ and $4 \mathrm{~km}$, respectively [3,7].

Chromatic dispersion significantly affects the quality of transmitted optical signals in fiber optical high-speed transmission systems, thus limiting the maximum transmission distance. This especially relates to the $40 \mathrm{Gbit} / \mathrm{s}$ data transmission speed, since in this case such a $\mathrm{CD}$ in a fiber worsens the compromise between speed and distance by a factor of 16 compared with that for $10 \mathrm{Gbit} / \mathrm{s}$ [4].

The negative effect of fiber CD increases rapidly with the data transmission rate increasing from $10 \mathrm{Gbit} / \mathrm{s}$ to $40 \mathrm{Gbit} / \mathrm{s}$. Therefore, it is of utmost importance to correctly choose a suitable compensation method for the employed combined HDWDM system. We have implemented three advanced modulation formats: NRZ-OOK, NRZ-DPSK, and 2-POLSK for the use at two transmission speeds: $10 \mathrm{Gbit} / \mathrm{s}$ and $40 \mathrm{Gbit} / \mathrm{s}$ in our HDWDM system. Our challenge was to find the CD compensation scheme that would be best suited for a highly complicated combined FOTS.

\section{THE PERFORMANCE EVALUATION OF WDM TECHNOLOGY}

Wavelength division multiplexing (WDM) was developed and introduced in order to make use of the $365 \mathrm{~nm}$ bandwidth offered by silica optical fibers. Later on, this technology was used to benefit from new degrees of freedom provided by possibility to manipulate the different wavelengths for selecting, dropping, adding and routing channels with a different channel's central frequencies [1]. The bandwidth of $365 \mathrm{~nm}$ of a single-mode optical fiber is obtained by assuming that the WDM system's channels can be located in the range from $1260 \mathrm{~nm}$ to $1625 \mathrm{~nm}$, which, according to ITU G.694.2 recommendation, is the $O$-band's left and the $L$ band's right margins, respectively. Since the first demonstration of this technology, the capacities $>10 \mathrm{Tbit} / \mathrm{s}$ in a single fiber and a record distance over $10000 \mathrm{~km}$ without the need to restore electrical regeneration have been reported [1]. 
Recent experimental advances and research works can be divided into three groups of so-called "hero" experiments regarding the maximum system's capacity, maximum spectral efficiency and maximum transmission distance oriented experiments [6]. We have adopted the main ideas of these experiments and are now offering a solution for mixed data rate combined WDM systems.

Basically, four ways exist for raising the maximum capacity of optical transmission systems. The first one is to maximize the capacity of existing systems prior to installing new fiber lines. The second one is to increase the number of transmitted channels. In WDM systems this is achieved by reducing the channel spacing or by using new transmission bands (such as $S$ - and $L$-bands in addition to the $C$ band as mentioned above). In this case, the total transmission capacity increment is achieved only by increasing the number of channels, as the individual transmission rate in each channel remains unchanged [2]. The third way consists in increasing the bit rate per channel. A higher channel rate increases the number of transmitted bits without requiring a greater number of transmitters. Even though new transmitters and receivers are necessary for higher transmission bit rates, the system cost only used to double when the bit rate was increased by factor 4 [3]. The only components of $10 \mathrm{Gbit} / \mathrm{s}$ systems which can be employed in new $40 \mathrm{Gbit} / \mathrm{s}$ systems are fibers, boosters and some externally modulated lasers [2]. It should be noted that currently the maximum bit rate per channel in pure WDM systems is limited by the maximum speed of electronic circuitries, because the electronic circuitry for bit rates of $80 \mathrm{Gbit} / \mathrm{s}$ and greater is still in a development stage and is unavailable for commercial use [7]. Finally, the fourth way is to raise the total transmission capacity using the channel compaction with simultaneous transmission bit rate increment for separate channels [2].

For a WDM system with $N$ channels spaced $\Delta f \mathrm{GHz}$ apart, each channel having $B \mathrm{Gbit} / \mathrm{s}$ bit rate, the total capacity is $\mathrm{C}=\mathrm{N} \cdot \mathrm{B}$, while the spectral efficiency is defined as $S E=B / \Delta f$ (in bit/s/Hz) $[1,8,9]$. However, we cannot use this $S E$ expression for the mixed data rate WDM systems because the bit rate of a system's channels may vary by a factor of four or even 16 [8]. Therefore, a new methodo$\operatorname{logy}$ for $S E$ calculation in combined WDM systems has been worked out. Assuming that we operate with discrete noiseless channels and all the sent information is received unchanged at the other end (BER $\rightarrow 0$ ) the $S E$ is calculated by the following formula:

$$
S E=\frac{\sum_{i=1}^{N} B_{j}}{N \Delta f},
$$

where $N$ is the number of channels in WDM system;

$B$ is the bit rate per channel, $(10,40 \mathrm{Gbit} / \mathrm{s})$;

$\Delta f$ is the channel spacing, $\mathrm{GHz}$;

$S E$ is the spectral efficiency, bit/s/ $\mathrm{Hz}$ [3].

The $S E$ maximizing ensures that the highest possible capacity can be transmitted over a bandwidth otherwise limited to the low-loss region of optical fiber and to the wavelength ranges where optical amplification can be achieved [1]. For enabling achievement of spectral efficiency exceeding $0.2 \mathrm{bit} / \mathrm{s} / \mathrm{Hz}$, some novel technologies are used, such as advanced modulation formats and orthogonal po- 
larization between adjacent channels. The maximal $S E$ which can be achieved with traditional on-off keying (OOK) or amplitude shift keying (ASK) modulations formats is $0.4 \mathrm{bit} / \mathrm{s} / \mathrm{Hz}$. It has been reported that using such advanced modulation format as differential phase shift keying (DPSK) the $S E$ of $0.8 \mathrm{bit} / \mathrm{s} / \mathrm{Hz}$ can be achieved. Using simultaneously such techniques as polarization division multiplexing (PDM) and differential quadrature phase shift keying (DQPSK) or differential phase shift keying with amplitude shift keying (QPASK) modulation formats, we can obtain $S E=1.6 \mathrm{bit} / \mathrm{s} / \mathrm{Hz}$ [9].

Increasing the spectral efficiency leads to enhancement of signal degradation mechanisms in optical fibers. In FOTSs, the degradation effects can be categorized into the random noise and the waveform distortions. For multi-span optically amplified systems the major source of receiver noise is the amplified spontaneous emission (ASE) generated by optical amplifiers, e.g. by the erbium-doped fiber amplifier (EDFA), which generates ASE noise in its active zone. In turn, the signal waveform distortion can be caused by linear chromatic dispersion (CD), polarization mode dispersion (PMD), fiber nonlinearity and/or their combinations. In multi-wavelength HDWDM systems the factor limiting the channel spacing reduction (and thus the spectral efficiency increase) is the inter-channel crosstalk.

This crosstalk originates in signal optical filtering and optical fiber nonlinearities, such as cross-phase modulation (XPM), self-phase modulation (SPM) and four-wave mixing (FWM) [10]. In order to reduce the impact of these effects (not only to obtain the maximum SE), various advanced optical signal modulation formats (such as DPSK and 2-POLSK, as mentioned above) are being increasingly studied from the information theory point of view. These formats are offered as an alternative to currently used traditional on-off keying. In this way manipulated signals are significantly distorted at high speed and high spectral density transmission conditions [2].

In general, the choice of optimum optical modulation format for a particular system depends on such factors as fiber types, bit rate per channel, channel spacing, dispersion compensation method, span length between two built-in optical amplifiers, and so on [11]. The $40 \mathrm{Gbit} / \mathrm{s}$ transmission systems should possess improved characteristics in terms of capacity-distance relation, because the already existing $10 \mathrm{Gbit} / \mathrm{s}$ systems enable long-haul transmission (over several thousands of kilometers) [6].

The simulation model (which is used in CD investigation and comparison methods of this work) of a combined HDWDM system is offered as a part of the common transmission system modernization strategy. This is only one possible transition stage from the traditional WDM systems to HDWDM systems with higher transmission capacity. In fact, it is replacement of the $10 \mathrm{Gbit} / \mathrm{s}$ channels and the NRZ-OOK modulation formats by $40 \mathrm{Gbit} / \mathrm{s}$ channels and the advanced modulation formats, such as NRZ-DPSK and 2-POLSK.

\section{CHROMATIC DISPERSION MANAGEMENT STRATEGIES}

Chromatic dispersion divides into waveguide and material dispersions [5]. The former is determined by the physical structure of optical fiber core and cladding (refractive index profile) where the resultant waves of different lengths propagate at differing velocities. The material dispersion is the dominant part of 
chromatic dispersion, being caused by change of the refractive index profile with wavelength [11]. As can be seen in Fig. 1, the waveguide dispersion is small as compared with the material one.

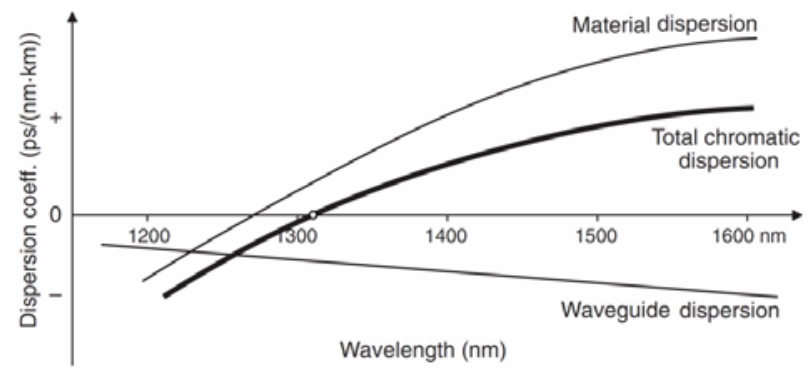

Fig. 1. The material, waveguide, and total chromatic dispersions of SSMF fiber [11].

For $\mathrm{CD}$ compensation the dispersion compensating fiber (DCF), the fiber Bragg grating (FBG) and the optical phase conjugator (OPC) can be used. The DCF has a large negative dispersion $(D=-80 \mathrm{ps} /(\mathrm{nm} \cdot \mathrm{km}))$ which helps to compensate the chromatic dispersion. Such an optical fiber is obtained by developing a complex refractive index profile. The effective core area $\left(A_{\text {eff }}\right)$ of a DCF is much smaller than that of a standard ITU-T G.652 single mode fiber, thereby the former experiences much higher optical signal distortions caused by nonlinear optical effects (NOEs). A typical dispersion compensating fiber has a small effective core area $\left(A_{\text {eff }}=12 \mu \mathrm{m}^{2}\right)$, whereas a standard single mode optical fiber $-A_{\text {eff }}=80 \mu \mathrm{m}^{2}$; in turn, the DCF has the attenuation coefficient up to $\alpha=0.6 \mathrm{~dB} / \mathrm{km}$, while a SSMF $-\alpha=0.2 \mathrm{~dB} / \mathrm{km}$. The impact of NOEs can be reduced by lowering the optical power $[5,12]$.

The chirped fiber Bragg grating (FBG) is an effective technology for CD compensation, because it is more suitable for large transmission capacity WDM systems. It has a grating period (GP) which is not constant but changes linearly over the length of the grating with a shorter GP located at the beginning of the grating. The FBG period is the distance between two adjacent maxima of the refractive index (Fig. 2).

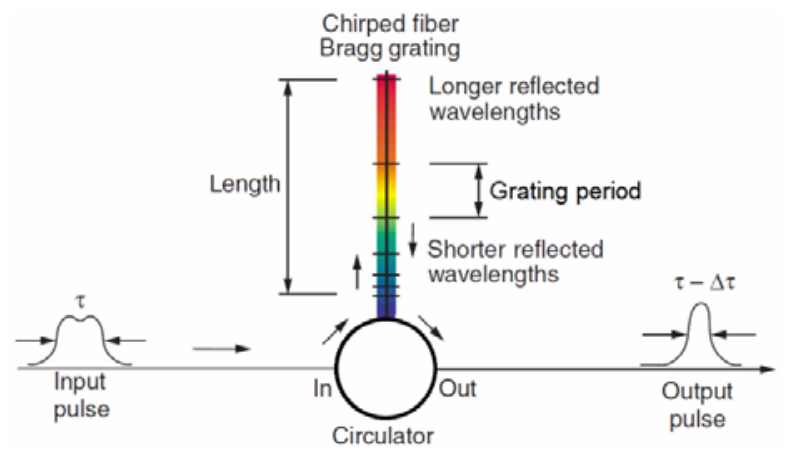

Fig. 2. Chirped fiber Bragg grating [11].

The fiber Bragg grating reflects a narrow spectrum of wavelengths that are centred at the reflected wavelength $\left(\lambda_{B}\right)$ and passes all the other wavelengths. As shown in Fig. 2, the dispersion-affected input pulse with width $\tau$ is passing the 
chirped FBG; at the output its width decreases by $\Delta \tau$, which restores its shape. Such a grating has shorter GPs at the beginning, but over the length of the grating these periods linearly increase. Therefore, the signals with shorter wavelengths are reflected sooner and have smaller delay of propagation through the FBG, while longer ones travel further into the fiber grating before they have been reflected back and have a greater propagation delay. Typically, the length of such a fiber grating is in the range $10-100 \mathrm{~cm}$ [11].

A significant advantage of the fiber Bragg grating over the DCF is its relatively low insertion loss. For comparison, commercial DCF specified to compensate accumulated chromatic dispersion of 100 to $120 \mathrm{~km}$ SSMF span have $\sim 10 \mathrm{~dB}$ of insertion loss, whereas for a FBG-based dispersion compensation unit capable of compensating the same fiber span length the insertion loss is only up to $4 \mathrm{~dB}$. In contrast to DCF, the fiber Bragg grating can be used at higher optical powers without inducing nonlinear optical effects.

The CD compensation methods described above will be practically implemented in our combined system model.

\section{SIMULATION SCHEME}

The simulation scheme of our combined HDWDM system model contains nine channels, which fall into three 3-channel groups with an identical transmitter and receiver block configuration but with different channel wavelengths. It was specially done in order to take into account linear and nonlinear crosstalk influence on the central group channels from the adjacent ones. The central group consists of channels numbered 1-3 (shown in Fig. 4), the left group - of channels 4-6, and right group - of channels 7-9. In further analysis of the system we will use only channels 1-3, while 4-6 and 7-9 will be considered as sources of transmission impairments.

In the first channel of our fiber transmission system the NRZ-OOK signal optical modulation format is employed. This format (traditionally used in optical transmission systems due to its relatively simple realization and historical domination [8, 12]) will serve as the reference for comparison of different modulation formats. The data transmission rate for this channel is chosen equal to $40 \mathrm{Gbit} / \mathrm{s}$. For channel 2 the POLSK modulation format was chosen, because it is the newest and, at the same time, the most promising modulation format for optical transmission systems [2]. In this case the per channel bit rate was chosen equal to $40 \mathrm{Gbit} / \mathrm{s}$. Finally, as the modulation format for the system's third channel the NRZ-DPSK was chosen, with per channel bit rate of $10 \mathrm{Gbit} / \mathrm{s}$.

The modulation format allocations to each system's channels were performed depending of what modulation format distribution among channels provides the lowest possible average BER for system channels at $10 \mathrm{Gbit} / \mathrm{s}$ per channel bit rate and $25 \mathrm{GHz}$ channel spacing, comparing with other five possible format distribution variants. As for per channel bit rate assignment, such a variant provides $S E=0.4 \mathrm{bit} / \mathrm{s} / \mathrm{Hz}$ and an average BER $\leq 10^{-40}$ (in the case of an ideal FBG used for CD compensation, see Fig. 3). Comparing with two other mixed data rate combined system variants that can provide $S E=0.4 \mathrm{bit} / \mathrm{s} / \mathrm{Hz}$, in this case BER $<10^{-12}$ or even $<10^{-14}$ can be secured, with the average channel BER $<10^{-40}$ [3]. Thus, for simulation model a transmission system with the following configuration was cho- 

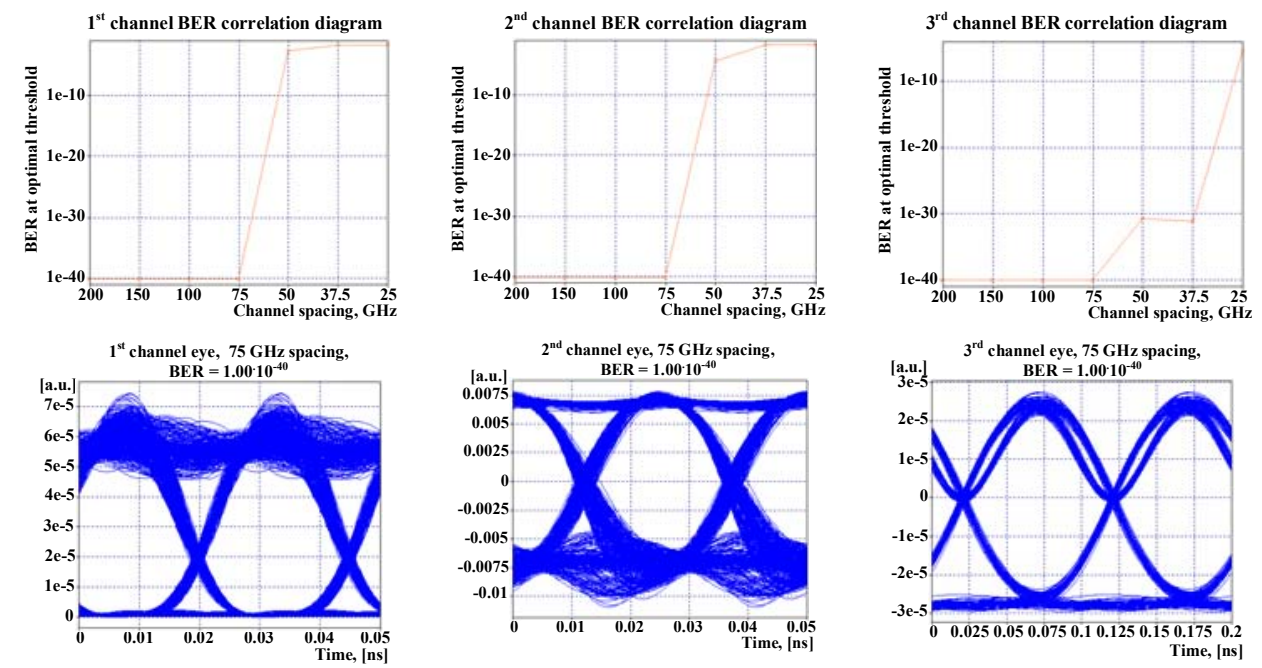

Fig. 3. Combined HDWDM system $1^{\text {st }} / 2^{\text {nd }} / 3^{\text {rd }}$ channel's BER correlation diagram, detected signals eye diagrams and BER values at $75 \mathrm{GHz}$ channel spacing.

As one can see in Fig. 3, the SE equal to $0.4 \mathrm{bit} / \mathrm{s} / \mathrm{Hz}$ was obtained in the case of a $75 \mathrm{GHz}$ interval for channel separation. This channel spacing value was chosen based on the establishment principle of ITU - T Recommendation G.694.1, which provides a frequency grid for dense wavelength division multiplexing (DWDM) applications. The frequency grid, anchored to $193.1 \mathrm{THz}$, supports a variety of channel spacings ranging from $12.5 \mathrm{GHz}$ to $100 \mathrm{GHz}$ and wider. Afterwards, all optical signals from nine channels are combined and transmitted through a $50 \mathrm{~km}$ SSMF using a $4 \mathrm{dBm}$ fixed output power optical amplifier (operating on the basis of EDFA). This amplifier is a necessary element since we simulate the optical signal transmission through one span of the ultra-long haul system.

The output power level is chosen equal to $4 \mathrm{dBm}$ since it can ensure the lowest average BER values for transmission channels of combined transmission systems of the mentioned above configuration but with a bit rate of $10 \mathrm{Gbit} / \mathrm{s}$ per channel and $25 \mathrm{GHz}$ channel spacing comparing with other fixed output power levels [3]. On the other fiber end the optical signals are filtered with optical Super Gaussian filters, converted to electrical signals and then electrically filtered using Bessel electrical filters (see Fig. 4).

The SSMF span length was chosen equal to $50 \mathrm{~km}$, because it is the maximum permissible between two EDFA in an ultra-long haul transmission system. Larger amplifier spacing in such a system would result in a prohibitive increase in the amplified spontaneous emission (ASE) noise. In order to achieve a greater range and information capacity, the amplifiers should be located close together, with the gain no greater than $10 \mathrm{~dB}$ and preferably less [2]. Further increase in the amplifier spacing will lead to stronger ASE noise influence and, as a result, to BER growth for each system channel. Besides, we should take into account the system's accumulated CD management strategy, which will be the main goal of our research. 


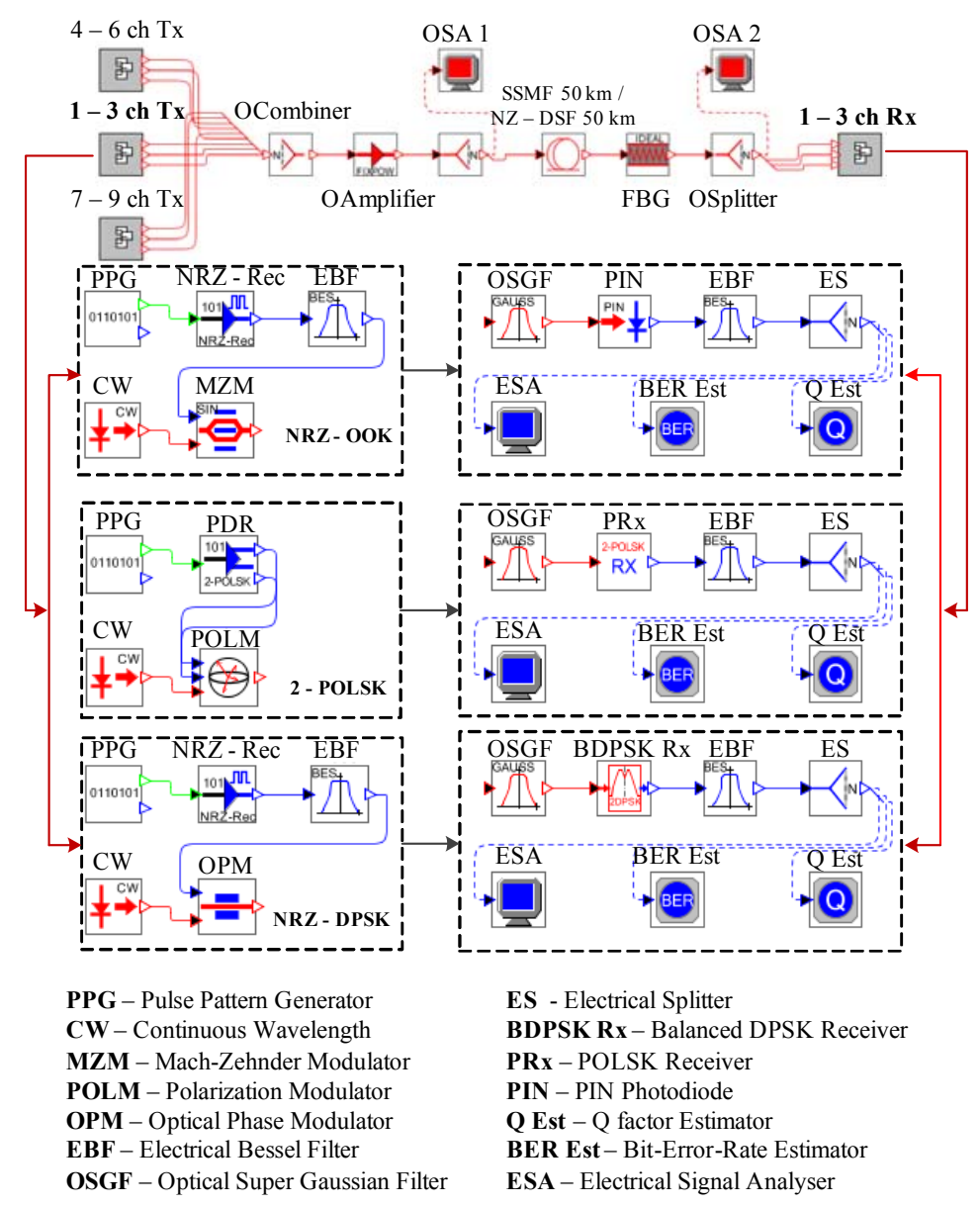

Fig. 4. Simulation scheme of 9-channel combined HDWDM system and channels' elements for transmitting and receiving the NRZ-OOK/ 2-POLSK/ NRZ-DPSK modulated optical signals.

Our accepted research method is mathematical simulation based on OptSim software, where complex sets of differential equations are solved using Split-Step algorithm. The optical fiber is affected by linear and nonlinear effects; electromagnetic field variation is described by the nonlinear Schrödinger equation (NLSE) [13].

In the FOTS simulations we used the Time Domain Split-Step (TDSS) method [12]. The principle of the method is illustrated by the signal propagation equation, which can be written as

$$
\frac{\partial A(t, z)}{\partial z}=\{L+N\} A(t, z)
$$

where $A(t, z)$ is the optical field;

$L \quad$ is the linear operator responsible for dispersion and other linear effects;

$N \quad$ is the non-linear operator that accounts for the Kerr effect and other NOEs (such as Stimulated Raman Scattering (SRS)). 
It is assumed that linear $(L)$ and nonlinear $(N)$ effects influence the optical signal independently if the step of simulated optical fiber $\Delta z$ is small enough. The fiber length $(z)$ is divided into small steps $\Delta z$ in order to take into account these linear and nonlinear effects in turn. To obtain accurate results, it is necessary to carefully choose step $\Delta z$. If this step is chosen too small, the calculation time will increase, while at a too large step the accuracy of calculations will be worse [12, 13].

For system's channel performance evaluation the $Q$-factor and the bit error ratio (with $\mathrm{BER} \leq 10^{-12}$ if $Q \geq 16.94 \mathrm{~dB}$ ) are employed:

$$
\begin{aligned}
& Q_{d B}=20 \lg \left[\frac{\mu_{1}-\mu_{0}}{\sigma_{1}-\sigma_{0}}\right] ; \\
& B E R=\frac{1}{2} \cdot \operatorname{erfc}\left(\frac{Q}{\sqrt{2}}\right) \approx \frac{e^{\frac{Q^{2}}{2}}}{\sqrt{2 \pi}\left[\left(1-\frac{1}{\pi}\right) Q+\frac{\sqrt{Q^{2}+2 \pi}}{\pi}\right]},
\end{aligned}
$$

where $\mu_{1,0}$ and $\sigma_{1,0}$ are the mean and the standard deviations of the received signal when logical " 1 " and " 0 " are transmitted.

\section{RESULTS AND DISCUSSION}

In this work, three methods for compensation of chromatic dispersion are described. These are: DCF, FBG and a DCF-FBG combination. While DCF and FBG are traditionally used CD compensation methods, as a better solution for practical realization a mixed DCF-FBG method is proposed. Using OptSim 5.1 software, all the three solutions have been realized; however, the new mixed DCFFBG compensation method is not the best solution for a transmission link that is already in use, because it is necessary to cut the optical fiber. In this work, we studied the ways of CD compensation that could be implemented on the transmitter or receiver side as close as possible to the beginning or the end of a fiber optical link. At these places it is possible to gain a direct access to the optical fiber and to place there the dispersion compensation modules.

As a result of our research, the mentioned above mixed solution has been worked out. This new DCF-FBG method can be implemented and adapted in already working combined FOTSs to improve the performance of these systems. This means the improvement of data transmission rate and/or transmission distance, with simultaneous securing of a system's stable operation with the recommended bit error ratio value $\left(\mathrm{BER}<10^{-12}\right.$ ).

In the case without dispersion compensation in our developed combined HDWDM simulation model, the performance of the $1^{\text {st }}$ and $2^{\text {nd }}$ channel is seriously affected by accumulated dispersion. The $3^{\text {rd }}$ channel is affected by accumulated CD to the same extent, but this channel's tolerance to this dispersion is much higher, since the NRZ-DPSK format is there employed as a coding one, and the optical signals are transmitted with a $10 \mathrm{Gbit} / \mathrm{s}$ per channel bit rate. As concerns the $1 \mathrm{st}$ and 2nd channels, without $\mathrm{CD}$ compensation the BER values are impermissibly high. It could be assumed that this is due to the inter-symbol interference (ISI), 
which causes pulse overlapping so that it is difficult to separate transmitted bit sequence at the receiver side. In this case the BER exceeds $10^{-12}$, the system performance is poor, and the fiber optical WDM transmission system is unable to qualitatively transmit the information over a distance of $50 \mathrm{~km}$ until the $\mathrm{CD}$ compensation is done (see Fig. 5).
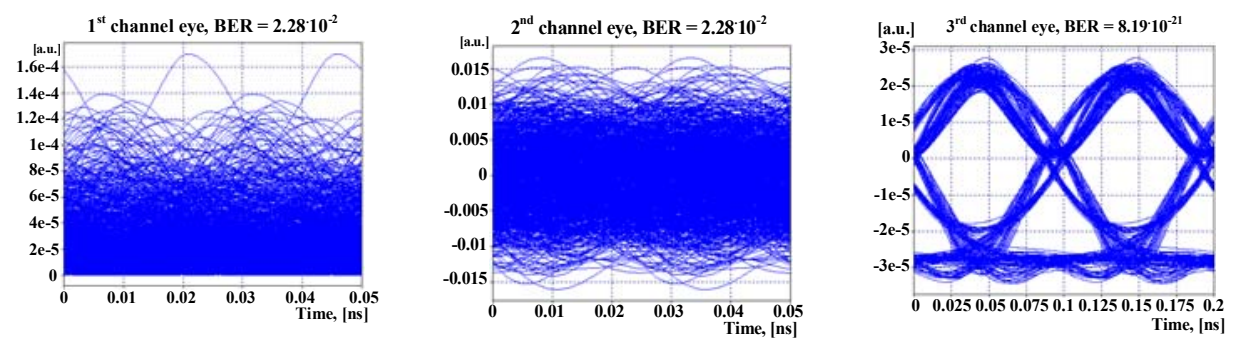

Fig. 5. Output eye diagrams for the $1^{\text {st }} \backslash 2^{\text {nd }} \backslash 3^{\text {rd }}$ channel of combined WDM system without $\mathrm{CD}$ compensation.

As one can see from the obtained eye diagrams of detected signal, the 3rd channel's eye is wide open and has almost the ideal form. This fact allows us to conclude that in this channel the error-free transmission is possible even without using the described CD compensation schemes. As for the $1^{\text {st }}$ and $2^{\text {nd }}$ system's channels, the CD compensation is of vital importance, since the openings of eye diagrams are completely closed there. This means that without $\mathrm{CD}$ compensation no signal transmission over a SSMF span of $50 \mathrm{~km}$ with BER $<10^{-12}$ is possible in these channels.

As follows from the name of the first realized compensation method (the DCF solution), it implies the implementation of dispersion compensating fiber. In our combined HDWDM system we have used pre- and post-compensation schemes for effective CD compensation and studied the best proportion of $\mathrm{LDCF}_{1}$ (DCF length on the transmitter side in $\mathrm{km}$, i.e. pre-compensation) and $\mathrm{LDCF}_{2}(\mathrm{DCF}$ length on the receiver side in $\mathrm{km}$, i.e. post-compensation). As shown in Fig. 6, we have found that the optimal required proportion is $5 / 5 \mathrm{~km}$.

The mentioned proportion was found by analyzing the $Q$-factor correlation diagrams. As one can see from such diagram for the $2^{\text {nd }}$ channel (the system's worst channel), the highest value $(20.75 \mathrm{~dB})$ is for the DCF length proportion equal to $5 / 5 \mathrm{~km}$; the proportion was chosen based on the $2^{\text {nd }}$ channel's $Q$-factor, since this channel is the most affected by transmission impairments and has the BER values higher than for the $1^{\text {st }}$ and $3^{\text {rd }}$ channels. The use of two DCF spans of $5 \mathrm{~km}$ in length provides the best $\mathrm{CD}$ compensation results for our investigated combined fiber optical transmission system.

The second realized compensation method is based on the use of fiber Bragg grating (FBG). At the first stage, we changed the FBG compensated CD value from $-1000 \mathrm{ps} / \mathrm{nm}$ to $-600 \mathrm{ps} / \mathrm{nm}$ with a $25 \mathrm{ps} / \mathrm{nm}$ step, and found that the optimal compensation level providing BER $<10^{-12}$ is equal to $-750 \mathrm{ps} / \mathrm{nm}$. As displayed in Fig. 7, the best BER results for the 1st and 2 nd channels can be achieved if we compensate completely the $\mathrm{CD}$ accumulated during the optical signal transmission over a $50 \mathrm{~km}$ SSMF $(800 \mathrm{ps} / \mathrm{nm})$. The optimal compensation level was chosen based on the BER results obtained for the $1^{\text {st }}$ channel of the combined WDM 
system. If we overcompensate the accumulated dispersion (i.e. if the compensated CD level exceeds $-875 \mathrm{ps} / \mathrm{nm}$ ) the BER value will grow rapidly, exceeding soon the $10^{-12}$ value obtained for the system's $1^{\text {st }}$ channel.
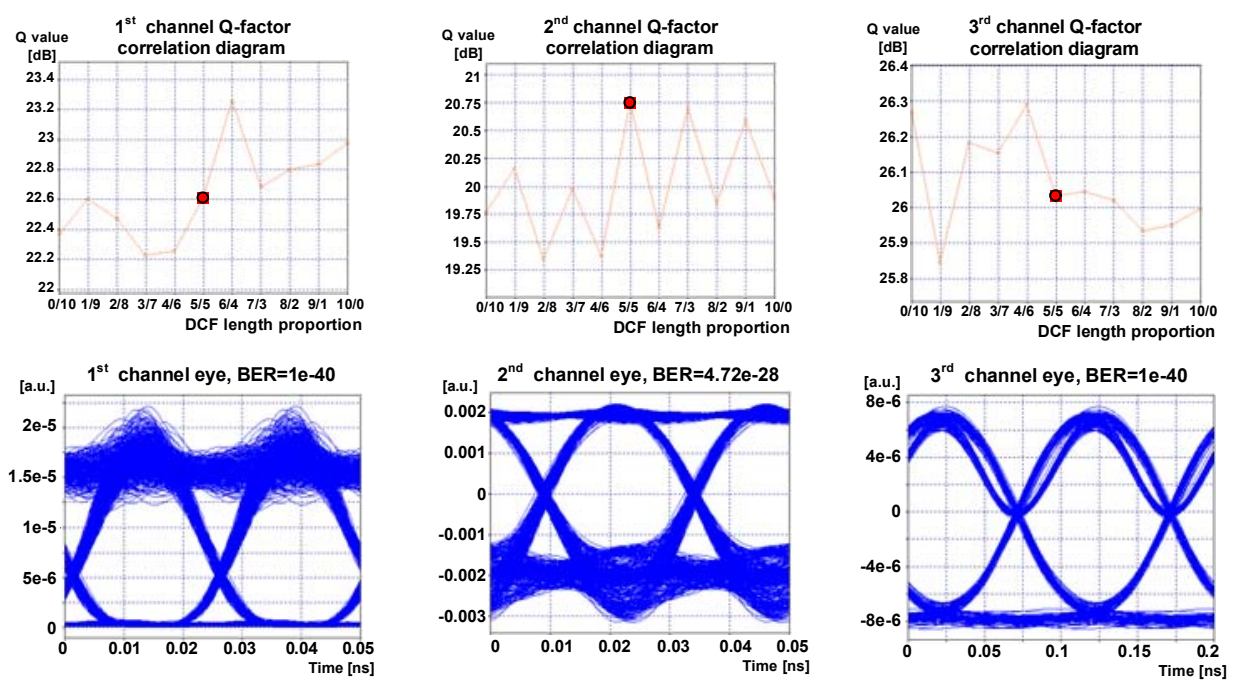

Fig. 6. Combined HDWDM system $1^{\text {st }} / 2^{\text {nd }} / 3^{\text {rd }}$ channel's Q-factor correlation diagrams, detected signals eye diagrams and BER values at $75 \mathrm{GHz}$ channel spacing.
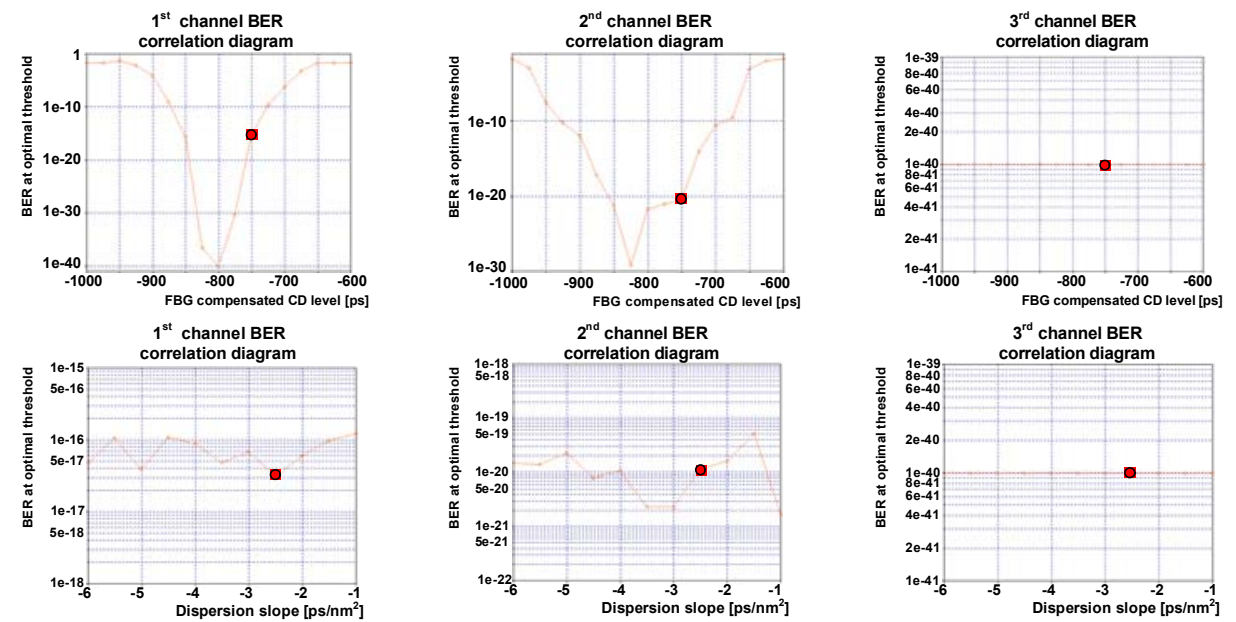

$1^{\text {st }}$ channel eye, $B E R=3.11 \cdot 10^{-17}$
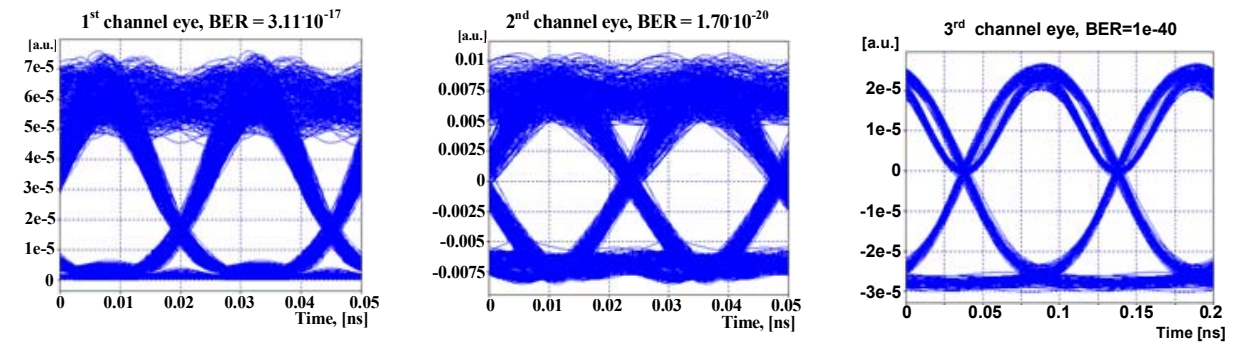

Fig. 7. Combined HDWDM system $1^{\text {st }} / 2^{\text {nd }} / 3^{\text {rd }}$ channel's BER correlation diagrams showing the detected signals' BER as a function of compensated CD level and a function of compensated dispersion slope at the $750 \mathrm{ps} / \mathrm{nm}$ CD level. The eye diagrams of detected signals and $\mathrm{BER}$ are shown for chosen compensated $\mathrm{CD}$ and slope values. 
At the second stage, we investigated the optimal dispersion slope compensation for the case of FBG used in our simulation scheme. The dispersion slope values were changed in the range from $-6 \mathrm{ps} / \mathrm{nm}^{2}$ to $-1 \mathrm{ps} / \mathrm{nm}^{2}$, with a $0.5 \mathrm{ps} / \mathrm{nm}^{2}$ step. As shown in Fig. 7, the optimal dispersion slope was chosen equal to $-2.5 \mathrm{ps} / \mathrm{nm}^{2}$. This value was found based on the first channel's BER value at the above mentioned dispersion slope (since the BER for this channel is higher than for the $2^{\text {nd }}$ channel, while for the $3^{\text {rd }}$ it does not depend on the compensated $\mathrm{CD}$ and dispersion slope levels, see Fig. 7).

For comparison, if we use the DCF pre- and post-compensation modules to compensate the $750 \mathrm{ps} / \mathrm{nm}$ level of accumulated $\mathrm{CD}$, the worst system's channel $\left(1^{\text {st }}\right)$ BER is $2.78 \cdot 10^{-14}(Q=17.60 \mathrm{~dB})$. This value was obtained for the DCF length proportion being $7: 3$. Numerically, this means that the pre-compensation module compensates $525 \mathrm{ps} / \mathrm{nm}$, whereas the post-compensation module $-225 \mathrm{ps} / \mathrm{nm}$. As one can see, despite the fact that the DCF length proportion 5:5 provides better BER results for the $2^{\text {nd }}$ system's channel, it is not securing the optimal $Q$ (BER) for each system's channel. For the 1 st (worst) channel BER $=2.34 \cdot 10^{-13}(Q=$ $=17.28 \mathrm{~dB}$ ) if the DCF length proportion used in pre- and post-compensation modules is 5:5.

The last tested $\mathrm{CD}$ method is a mixed one, including the commonly used dispersion compensating fiber (DCF) and fiber Bragg grating (FBG) into our combined FOTS and thus designated as DCF-FBG. In the pre-compensation module a DCF will be used, while in the post-compensation one - an FBG. For dispersion compensation we reduced the DCF length (LDCF) from 15 to $0 \mathrm{~km}$, with a $1 \mathrm{~km}$ step to find the optimal DCF length and FBG dispersion compensation level proportion, see Fig 8 . The DCF dispersion $D=-80 \mathrm{ps} / \mathrm{nm} / \mathrm{km}$ and the total accumulated dispersion in a fiber optical link that should be compensated is $-750 \mathrm{ps} / \mathrm{nm}$ to obtain the BER in each system's channel lower than $10^{-12}$ (as indicated in the previous section).
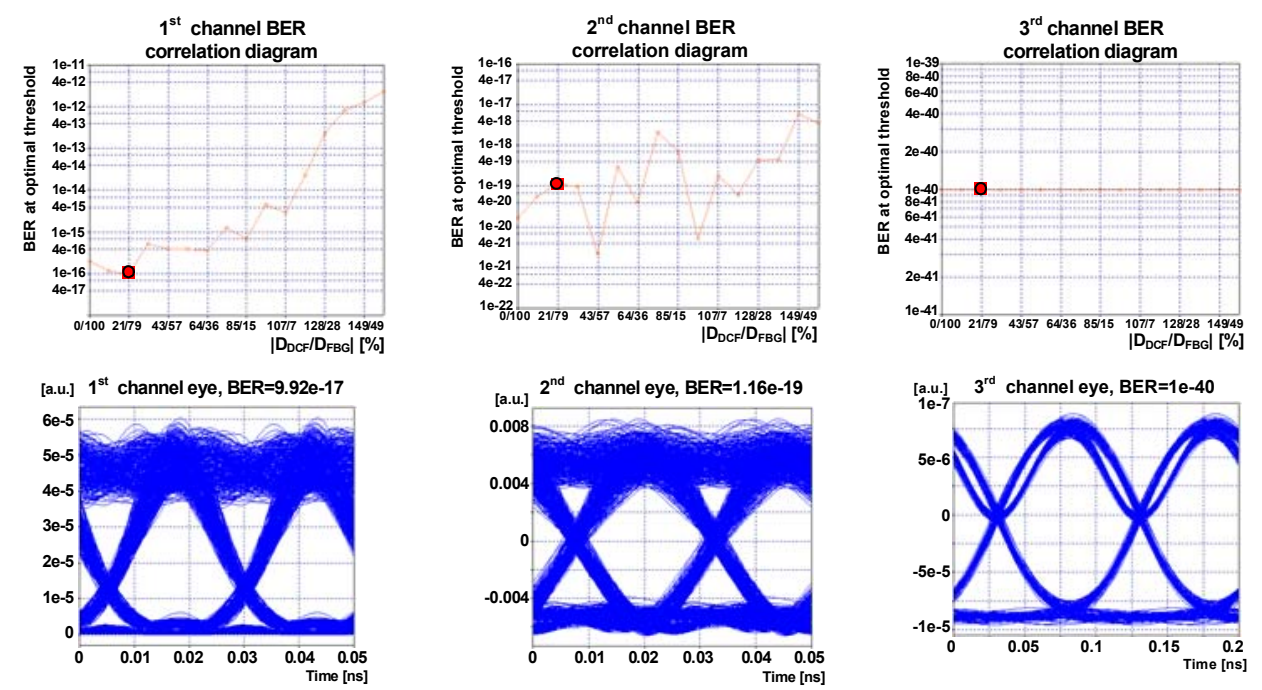

Fig. 8. Combined HDWDM system $1^{\text {st }} / 2^{\text {nd }} / 3^{\text {rd }}$ channel's BER correlation diagrams, eye diagrams of detected signals and BER at optimal DCF-FBG dispersion compensation proportion. 
Therefore, we used the following formula: $\mathrm{DFBG}=-750+80$ (LDCF), where DFBG is the FBG-compensated CD level. The chromatic dispersion that can be compensated by a DCF fiber can be expressed as DDCF $=-80 \mathrm{LDCF}$.

As one can see in Fig. 8, the optimal proportion |DDCF/DFBG| is $21 / 79 \%$. This means that $21 \%$ of the $-750 \mathrm{ps} / \mathrm{nm}$ value should be compensated by DCF, whereas remaining $79 \%$ - by FBG. Numerically, for our investigated system this means that the DCF compensates $160 \mathrm{ps} / \mathrm{nm}$ (i.e. $2 \mathrm{~km}$ of DCF are used), while FBG - the remaining $590 \mathrm{ps} / \mathrm{nm}$ of the accumulated CD. This proportion was found for the BER in the $1^{\text {st }}$ channel as the most affected by chromatic dispersion due to the use of NRZ-OOK format for optical signal modulation in this channel. This format has a lower CD tolerance as compared with the 2-POLSK and NRZ-DPSK formats.

The found DCF-FBG proportion is recommended for optimal accumulated CD compensation in the [NRZ-OOK (40 Gbit/s, 193.025 THz)] - [2-POLSK (40 Gbit/s, $193.100 \mathrm{THz})]$ - [NRZ-DPSK (10 Gbit/s, $193.175 \mathrm{THz})]$ combined fiber optical transmission system.

\section{CONCLUSIONS}

We have evaluated the suitability of different chromatic dispersion compensation methods for the most efficient high-speed combined HDWDM system with a $50 \mathrm{~km}$ SSMF and the configuration with the following parameters of the channel's number, modulation format, per-channel data rate and channels' central frequencies at $75 \mathrm{GHz}$ channel spacing: [1 ${ }^{\text {st }}$ channel: NRZ-OOK, $40 \mathrm{Gbit} / \mathrm{s}$, $193.025 \mathrm{THz}]-\left[2^{\text {nd }}\right.$ channel: $\left.2-P O L S K, 40 \mathrm{Gbit} / \mathrm{s}, 193.100 \mathrm{THz}\right]-\left[3^{\text {rd }}\right.$ channel: NRZ-DPSK, $10 \mathrm{Gbit} / \mathrm{s}, 193.175 \mathrm{THz}]$.

The recommendations and conclusions for the next generation of WDM transmission systems are as follows.

- The use of both CD pre- and post-compensation modules together, which might contain DCFs of different length, allow achieving better system's BER as compared with the case of using these modules separately. We have found that the best $\mathrm{CD}$ compensation and BER results for the investigated combined HDWDM system with mixed data rates can be achieved using a 5 $\mathrm{km}$ span of DCF in pre- and post-compensation modules. Similar results can be achieved using $7 \mathrm{~km}$ of DCF in the pre-compensation module and $3 \mathrm{~km}$ in the post-compensation one.

- The minimum CD level that is to be compensated using FBG to achieve BER $<10^{-12}$ in the combined HDWDM system channels is $750 \mathrm{ps} / \mathrm{nm}$, without dispersion slope compensation. In the case of $-2.5 \mathrm{ps} / \mathrm{nm}^{2} \mathrm{CD}$ slope compensation in addition to the $750 \mathrm{ps} / \mathrm{nm}^{2} \mathrm{CD}$ level compensation the worst channel's (NRZ-OOK) $Q$-factor increases by $0.17 \mathrm{~dB}$ (from $18.25 \mathrm{~dB}$ to $18.42 \mathrm{~dB}$ ).

- The combined DCF-FBG method (with the former used in the pre-compensation module and the latter - in the post-compensation one) allows achieving the least average channel's BER if the dispersion compensated by DCF and FBG is $21 \%$ and $79 \%$ of the minimum accumulated CD level that 
should be compensated in order to obtain BER $<10^{-12}$ in each system's channel. In our case this level is $750 \mathrm{ps} / \mathrm{nm}$. Similar results could be obtained if the $57 / 43 \%$ dispersion level compensation proportion is used for the realized combined HDWDM system.

\title{
ACKNOWLEDGEMENT
}

This work has been supported by the European Regional Development Fund in Latvia within the project Nr. 2010/0270/2DP/2.1.1.1.0/10/APIA/VIAA/002.

\section{REFERENCES}

1. Peucheret, C. (2004). Fibre and component induced limitations in high capacity optical networks. Doctoral thesis. 1-8.

2. Udalcovs, A., Bobrovs, V., \& Ivanovs, G. (2011). Investigation of allowed channel spacing for differently modulated optical signals in combined HDWDM systems. Lithuanian Journal of Electronics and Electrical Engineering, 5 (111).

3. Udalcovs, A. (2011). Investigation of combined transmission in WDM systems. Master's thesis. 135.

4. Hamano, H., Ishikawa, G. \&, Yamashita, K. (1999). High - speed transmission systems. Fujitsu Sci. Tech. J., 35 (1), 91-99.

5. Keiser, G. (2007). Optical Communications Essentials. McGraw-Hill, 372.

6. Hodzic, A. (2004). Investigations of high bit rate optical transmission systems employing a channel data rate of $40 \mathrm{~Gb} / \mathrm{s}$. Doctoral thesis. 1-5.

7. Clarke, A. (2007). Optical pulse processing towards $\mathrm{Tb} / \mathrm{s}$ high - speed photonic systems. Doctoral thesis. 1-14.

8. Bobrovs, V. \& Ivanovs, G. (2008). Investigation of mixed data rate and format transmission in WDM networks. Lithuanian Journal of Electronics and Electrical Engineering, 4 (84), 63-66.

9. Xu, C., Liu, X., \& Wei, X. (2004). Differential phase-shift keying for high spectral efficiency optical transmissions. IEEE Journal of Selected Topics in Quantum Electronics, 10 (2), 281-293.

10. Bobrovs, V., \& Ivanovs, G. (2009). Investigation of minimal channel spacing in HDWDM systems. Lithuanian Journal of Electronics and Electrical Engineering, 4 (92), 53-56.

11. Chomycz, B. (2009). Planning Fiber Optic Networks. McGraw-Hill, 401.

12. Bobrovs, V. (2010). Analyzing and Evaluation of Channel Interval in Wavelength Division Multiplexing Transmission Systems. Summary of promotion work. 13-15.

13. Bobrovs, V., Ivanovs, G., \& Spolitis S. (2011). Realization of combined chromatic dispersion compensation methods in high speed WDM optical transmission systems. Lithuanian Journal of Electronics and Electrical Engineering, 5 (111).

\section{HROMATISKĀS DISPERSIJAS KOMPENSĀCIJAS METOŽU IZPĒTE KOMBINĒTĀM HDWDM SISTĒMĀM}

\author{
V. Bobrovs, A. Udalıcovs, S. Spolītis, Ģ. Ivanovs
}

Kopsavilkums

Autori ir izpētījuši vispiemērotākās hromatiskās dispersijas (CD) kompensācijas shēmas realizāciju ātrdarbīgā HDWDM sistēmā ar dažādi modulêtiem 
optiskajiem signāliem un jauktu pārraides ātrumu. Šì pētījuma pamatā ir OptSim 5.1 simulācijas programmatūras izmantošana, kura, skaitliski, izmantojot sadalesolis Furjē metodi, risina nelineāro Šrēdingera vienādojumu. Darbā ir parādīts, ka hromatiskās dispersijas kompensācijas shēmai ir izškiiroša loma, lai uzlabotu kombinētas HDWDM sistēmas veiktspēju. Lai palielinātu pārraides ātrumu kanālā četras reizes, ir nepieciešams pielietot dispersijas pārvaldības stratēǵiju. Līdz ar to, tika atrasts vispiemērotākais hromatiskās dispersijas kompensācijas risinājums samērā sarežğîtas kombinētas šķiedru optikas pārraides sistēmas gadījumā. Tika atklāts, ka asimetrisko hromatiskās dispersijas kompensācijas shēmu izmantošana pirms- un pēc-kompensācijas moduḷos ir visefektīvākā un ļauj sasniegt vislabākās iespējamās BER vērtības sistēmas kanālos.

27.04.2011. 